\title{
INDEX ON CENSORSHIP
}

\section{Book Review}

\section{Review: Volume 40 Number 3 - 2011}

\section{Umit Inatci, Eastern Mediterranean University, North Cyprus}

When we think, talk and write about censorship in the art world, usually we consider only the freedom of expression but not the creative freedom as a controversy relation with the authorities. Artists - suppose they are anti conformist- always are interested $\mathrm{f}$ in the intellectual conflict. Therefore we cannot have a critical view unless this crucial psychosocial aspect is not mentioned.

Just a week ago, I was discussing with a curator and art critic Bruno Cora about the artist capability of converting suitable circumstances in to the inconvenient situations for authorities that they don't like any political turbulences. He told me all about Ai Weiwei, his problems with Chinese regime and the interesting case happened when Jannis Kounellis was in China to exhibit his works. Ai Weiwei obtained permission from the authorities just to visit Kounellis exhibition. He did it and he visited him; as soon as they met, Ai Weiwei told to Kounellis: "I am here to see your exhibition because you are a great artist." Well it seems strange but considering the political rigidity of the Chinese authority, to obtain permission while one is in the prison, for any exhibition visit, is something to discuss on it. As we can notice, there is a sort of fanny and ambiguous feelings, such a respect and hatred between authority and the artist who does not hesitate to oppose with dignity.

Of course, there are some extreme cases that, because of their dramatic situation the consequences are not so happy; especially when we speak about religion related cases, as Islamic countries. In this case, the problematic is not deriving from the ideological conflict but from the manner of Islamic interpretation of representation. Speaking about fundamental level is extremely difficult to produce expression and behavior if they are merely not approved in Koran. 
There is another kind of situation that can put us in difficult position of judging. As the Art Issue concerns on page 176* speaking about the destiny of Mehmet Aksoy's sculpture in Turkey, I personally as an artist and member of the International Plastic Arts Association followed all stages of this embarrassing case. First of all, Mehmet Aksoy had never been in contradiction or conflict with Turkish authorities till this situation appeared. He always had support and profitable relations with bureaucracy. "Monument to Humanity by sculptor Mehmet Aksoy was removed from display on 26 January 2011. The artwork, which was described by Prime Minister Recep Tayyip Erdogan as 'freakish', depicted the friendship between Turkish and Armenian people."* To be frank, I personally was one of the artists that did not like the idea of installing brut cement sculpture (as usually they did in totalitarian regimes) in the archeological site. Second, it was depreciatory to oppress with the monumental mass the rural character of the place with some Ottoman architecture nearby. Massive cement installed in the middle of nature without considering environmental character of the place was not really correct decision taken by the previous local authority. All the rest, political engagement of some figure like Bedri Baykam (chair of Artist Association) was only opportunistic behavior against new Islamic trended government.

Obviously freedom of expression in art has another political characteristic and cannot be framed in this kind of specific argument. But since I read with pleasure and satisfaction the art issue I felt necessity to emphasize this kind of ambiguities that can drive the attention of the reader in irrelevant discussions. This kind of problematic can teach us that it is necessary to analyses each case with its circumstances. We cannot deny that "political expression had irreversibly entered the artistic establishment" as the issue concerns, and naturally for many countries as Russia "artist and activists are targeted with the same legislation". This is another case to point out. Question (?): are they, activist acting as an artist or artist involved in political action? Well, it does not make any difference since we talk about freedom of expression. But the problem occurs when artist claim more freedom on behalf of artistic excuse. Art is risk! Artist does not ask privilege for his acts. It is natural that if authorities don't react, artist automatically is ignored. So, so called intellectual conflict between artist and authorities, in a way, is desired by artist himself. Otherwise is difficult to attract attention of the masses. Therefore -if we refer to John Frohnmayer reports- I am not sure if the artist has to know how to survive a political ambush or politicians to survive an artistic ambush. It 
is necessary to not underestimate the intellectual power of art, and reduce art in to the power struggle between artists and politicians.

Index on Censorship - the Art Issue, give us a multi lateral view about censorship in art. We can reflect and tray to confront and comparison different situations according different conditions. I would share fully what Eugenio Merino says (p. 76) in this art issue about freedom of expression and censorship in art -to say the last: "The freedom to create and express oneself is right that places obstacles in the path of the censorship of artistic expression or at least legitimizes our desire to work without restrictions. This means that we are not in the service of anything or anyone, neither religion, politics nor society. We are only motivated by our ideas and convictions, and it is this that makes art something more than a beautiful object." 